\title{
Crença, Regra e AçÃo
}

\author{
Luiz Henrique de AraúJo Dutra \\ Universidade Federal de Santa Catarina/CNPq
}

\begin{abstract}
In this paper I analyze the relation between ascribing knowledge to a human agent in two kinds of circumstances, namely acting according to environmental contingences and acting according to a rule. My discussion begins with the distinction I put forward between descriptive and explicative hypotheses. After relating the notions of rule and belief, I try to support the idea that modifications in overt behavior are prior to any ascriptions of knowledge to an agent, connecting this topic with processes of investigation. I discuss also if there can be beliefs which do not bring about modifications of behavior, and I argue that in certain circumstances of our investigation about the behavior of people, in order to give it unity, we are to ascribe beliefs of that kind to people. Given those points, I depict epistemology as the theory of the processes of investigation involved in human action.
\end{abstract}

Keywords: Epistemology, cognitivism, behaviorism, environmentalism, beliefs, rules, action.

Uma das principais atividades dos seres humanos consiste na observação e interpretação do comportamento uns dos outros. Cada um de nós gasta um considerável número de horas semanais - senão diárias - tentando entender o que outras pessoas estão fazendo ou fizeram, suas razões e seus propósitos, o que pensam elas quando agem de determinadas maneiras, e assim por diante. Entre as pessoas observadas - e mesmo estudadas — por alguém está também ele próprio. Desejamos entender o que fazemos ou fizemos, muitas vezes, contra nossos próprios propósitos e convicções. Também por isso os consultórios dos psicoterapeutas estão sempre lotados.

Não é apenas por mero passatempo ou curiosidade que queremos entender nosso comportamento. Trata-se de uma necessidade prática, como sabemos bem — uma necessidade muitas vezes crucial. Saber ou não o que as pessoas são capazes de fazer em determinadas circunstâncias pode trazer consequências práticas favoráveis ou desfavoráveis de grande importância - consequências que não se limitam ao alívio que alguém pode experimentar quando entende por que fez algo que não gostaria de ter feito ou por que determinada pessoa agiu contrariamente às expectativas. Estarmos munidos das ferramentas adequadas para analisar o comportamento das pessoas e para prever seu curso de ação é uma das maiores necessidades da vida social. Não é preciso dar exemplos aqui, pois cada um de nós é capaz de se reconhecer nesse papel de estudioso — ainda que amador — do comportamento humano em inúmeras circunstâncias.

Principia 14(2): 279-308 (2010).

Published by NEL — Epistemology and Logic Research Group, Federal University of Santa Catarina (UFSC), Brazil. 
O conhecimento é algo importante em nossa análise quotidiana do comportamento das pessoas. Isto é, faz diferença ter em conta o que os outros sabem ou aquilo em que eles acreditam. Concebido de forma comportamental, ${ }^{1}$ o conhecimento pode ser interpretado como uma abstração que fazemos a partir da observação do comportamento de uma pessoa. Por exemplo, suponhamos que seja o caso de atribuir a determinado sujeito a crença (justificada ou não) de que vai chover. Provavelmente, fazemos isso porque observamos o indivíduo carregando um guarda-chuva, ou usando uma capa, ou, enfim, comportando-se de tal forma que seria razoável atribuir a ele determinado conhecimento ou crença a respeito do tempo.

Contudo, mesmo concebido de forma intelectualista ou mentalista, o conhecimento ainda é crucial para entendermos o comportamento das pessoas. Mesmo que queiramos que uma crença seja, por exemplo, uma representação mental que um indivíduo humano possui e que acarreta determinadas ações suas, ainda assim, é necessária uma ligação com seu comportamento manifesto para que tal atribuição a ele de uma crença seja pertinente. Não faria qualquer sentido, por exemplo, num dia de sol, e vendo que determinada pessoa não usa nem uma capa de chuva, nem carrega um guarda-chuva, nem exibe nenhum sinal exterior de uma suposta crença de que vai chover, atribuir a ela tal crença. Ainda que tal crença possa existir na pessoa como uma representação mental que não acarreta modificações em seu comportamento (pelo menos em seu comportamento presente), para nossa análise do comportamento, tal hipótese seria supérflua. Ela não será supérflua, contudo, se puder de algum modo ser ligada ao comportamento manifesto, mesmo que indiretamente.

Neste artigo, vamos analisar a questão da atribuição de conhecimento - ou conhecimentos, ou crenças e opiniões - às pessoas em correlação com a observação de seu comportamento manifesto. Há duas questões principais que são inevitáveis a esse respeito, entre outras, tal como os comentários acima já sugerem. Uma delas é aquela sobre a própria possibilidade de haver conhecimentos (crenças ou opiniões) que não provoquem modificações de comportamento. Em certo sentido, é preciso admitirmos que isso é possível, mas em determinadas condições - condições essas que, a nosso ver, dizem respeito a nossas investigações sobre o conhecimento e o comportamento de determinada pessoa de forma mais geral e abrangente, e não, propriamente falando, às condições nas quais se dá sua ação quando analisamos episódios isolados do que a pessoa faz.

Além disso, e principalmente, devemos também examinar a questão se a própria noção de conhecimento - ou, mais especificamente, de alguém possuir uma crença ou opinião - faria sentido independentemente de uma análise de seu comportamento manifesto. A esse respeito, a posição que vamos defender é aquela segundo a qual a própria noção de conhecimento (atribuído a alguém) é parasitária em relação à observação de modificações no comportamento manifesto (dessa pessoa). 
Antes de passarmos à discussão específica desses assuntos, é importante esclarecermos em que medida esse tipo de investigação diz respeito à teoria do conhecimento ou epistemologia, e não apenas à psicologia enquanto análise do comportamento manifesto. Em primeiro lugar, a posição anunciada no parágrafo anterior a respeito da segunda questão aludida já indica uma resposta também nesse caso. Se a noção de conhecimento aparece como uma hipótese destinada a explicar certas modificações de comportamento, então a teoria do conhecimento é forçosamente também uma disciplina comportamental.

Entretanto, além disso, é preciso reconhecer que não fica inteiramente claro o caráter de uma teoria do conhecimento puramente abstrata e independente dos processos psicológicos que conduzem ao conhecimento como produto ou resultado, apesar de ser isso defendido por diversos filósofos. ${ }^{2}$ Em outras palavras, o próprio termo "conhecimento" é ambíguo e pode denotar tanto aquilo a que chegamos por um processo de pensamento (ideias ou crenças, por exemplo, ou noções, conceitos, teorias, opiniões etc.), quanto o próprio processo pelo qual chegamos a tais coisas, isto é, aquilo que preferimos denominar cognição (embora esse termo seja por vezes também utilizado para indicar o resultado de tal processo).

Nesse segundo sentido, indicando um processo, é melhor então falarmos de investigação, e reservarmos o termo "conhecimento" apenas para o primeiro sentido, de um resultado. Mesmo assim, não fica claro se a teoria do conhecimento - aquela disciplina praticada tradicionalmente pelos filósofos - é uma teoria do conhecimento propriamente ou uma teoria da investigação ou da cognição. Há filósofos para defender ambos os pontos de vista. ${ }^{3}$ Assim, em parte, a presente discussão também terá como resultado tocar nesse ponto, e defendemos que a epistemologia é, antes de tudo, uma teoria da investigação. Ora, a investigação não pode ser um processo meramente mental, no sentido intelectualista tradicional, e isso ficará claro desde o início, ao discutirmos a segunda das questões principais acima mencionadas, pela qual vamos começar.

$\mathrm{Na}$ primeira seção, analisamos a relação entre a atribuição de conhecimentos (crenças, por exemplo) a um agente humano em duas situações-tipo diferentes, a saber, agir segundo as contingências ambientais e agir seguindo uma regra. Retomamos a distinção de Skinner (1969) entre o comportamento guiado por regras e o comportamento guiado por contingências ambientais. Propomos também uma distinção entre hipóteses descritivas e hipóteses explicativas. E examinamos então em que situações é pertinente atribuir algum conhecimento a um agente.

Após estabelecermos a relação entre as noções de regra e de crença, na segunda seção, discutimos uma das duas questões principais acima enunciadas, isto é, aquela a respeito da precedência das modificações de comportamento manifesto sobre qualquer atribuição de conhecimento ou crença a um agente humano, relacionando esse tópico com os processos de investigação.

Principia 14(2): 279-308 (2010). 
Na terceira seção, discutimos a outra questão acima levantada, a saber, se pode haver crenças que não acarretam modificações de comportamento. Defendemos que, em determinadas condições de nossa investigação sobre o comportamento das pessoas, para conferirmos unidade a seu comportamento, é legítimo atribuir a elas crenças desse tipo. E isso significa, em contrapartida, conferirmos também unidade ao conhecimento atribuído a tal pessoa e unidade entre suas crenças ou opiniões e sua ação.

Por fim, retomando os pontos principais das seções precedentes, discutimos o caráter da epistemologia como uma teoria da investigação, mais exatamente, como uma teoria sobre os processos de investigação envolvidos na ação humana, processos nos quais a crença ganha um lugar bem definido.

\section{Modificações de comportamento}

Skinner e outros behavioristas fazem uma distinção importante entre o comportamento regido pelas contingências (ou variáveis ambientais, ou circunstâncias, digamos - aquilo que Skinner denominou contingências do reforço) e o comportamento guiado por regras. ${ }^{4}$ A distinção é importante, sem dúvida, e tem valor não apenas pedagógico e heurístico para estudarmos o comportamento humano. Contudo, a diferença entre os comportamentos de seguir uma regra e de ser conduzido pelas contingências ou circunstâncias ambientais nem sempre é nítida na prática, isto é, na observação real de episódios do comportamento humano. ${ }^{5}$

De fato, fazer a distinção para entender um episódio de comportamento pode já ser um tiro no escuro, no sentido de estarmos levantando uma hipótese e indo além das aparências. Antes de prosseguirmos na discussão sobre esse ponto, gostaríamos de propor outra distinção que acreditamos ser aceitável e que, em grande medida, também é elucidativa sobre nosso trabalho de estudar o conhecimento humano e o comportamento cognitivo humano, da mesma forma como a distinção de Skinner pode ser elucidativa sobre o comportamento humano em geral.

Propomos distinguir entre hipóteses explicativas e hipóteses descritivas. Muitas vezes, confundimos os dois tipos de hipótese. Basicamente, em uma primeira aproximação, podemos dizer que uma hipótese descritiva apenas completa uma narração de um fato ou de determinados fatos, acrescentando elementos, isto é, acrescentando ex hipothesi informação que não foi obtida empiricamente, mas que, em princípio, poderia ser assim obtida. Uma hipótese explicativa, por sua vez, recorre a outro nível de conhecimentos para falar de determinados fatos. Via de regra, uma hipótese explicativa utiliza uma teoria (científica ou não) para produzir o entendimento de determinado(s) fato(s), acrescentando informação que não pode ser obtida empiricamente. ${ }^{6}$ 
Não devemos encarar, contudo, a diferença entre hipóteses descritivas e hipóteses explicativas como algo coincidente com a diferença entre os aspectos observáveis e inobserváveis do mundo. Podemos dizer no máximo que as duas distinções se recobrem parcialmente, e que as hipóteses descritivas tendem a recorrer a aspectos observáveis do mundo, enquanto que as hipóteses explicativas tendem a recorrer a aspectos inobserváveis do mundo. A distinção entre observável e inobservável, como sabemos, pode ser feita de forma linguística, dividindo os termos que utilizamos em dois vocabulários (um observacional e outro teórico), como foi feito pelos positivistas lógicos. Mais recentemente, contudo, e de uma forma alternativa, ela foi feita por Bas van Fraassen em viés factual e com respeito à capacidade humana de observar. Nesse caso, o que é observável e o que não é depende do que pode trazer informação aos seres humanos, dadas suas capacidades perceptivas sem ajuda, isto é, sem o recurso a aparelhos. ${ }^{7}$

Ao contrário do caráter semântico que possuem as duas maneiras acima mencionadas de fazer a distinção entre observável e inobservável, nossa distinção entre hipóteses meramente descritivas e hipóteses explicativas é de caráter pragmático. E embora ela possa coincidir parcialmente com a distinção entre observável e inobservável, seu foco é diferente, e se volta não apenas para os aspectos do mundo que são evocados na hipótese que é levantada, mas para as consequências que a própria hipótese traz, enquanto ferramenta de investigação, para a pesquisa a que se dirige. Os exemplos dados no restante deste artigo permitem esclarecer esse ponto, e mostrar que os dois tipos de hipóteses se diferenciam principalmente pelas consequências que produzem nas discussões que informam.

Vamos dar exemplos retornando ao caso dos comportamentos de seguir uma regra e de ser guiado por contingências ambientais. Se um indivíduo não conhece determinada cidade à qual chega e na qual quer encontrar certo endereço, pode pedir informação a um habitante local. Esse último, por sua vez, vai lhe explicar o caminho até aquele endereço, e o visitante vai seguir as instruções que lhe foram dadas, para poder chegar ao destino desejado. O habitante local, nesse caso, forneceu ao visitante uma regra, por assim dizer, que, uma vez seguida, vai levá-lo ao local pretendido.

Contudo, de sua parte, o habitante local, que já conhece a cidade, não precisaria seguir uma regra desse tipo para ir até o endereço em questão (uma regra de conduta, digamos, que poderia estar também implícita em um guia da cidade). Ele simplesmente caminharia pelas ruas, guiando-se por aqueles pontos de referência que já conhece. Esse habitante local estaria se comportando em função de variáveis ambientais. Ele não seguiria uma regra, no sentido em que estamos tomando o termo aqui, mas se guiaria pelas circunstâncias (ou por variáveis ambientais). ${ }^{8}$

Ao observarmos esses dois indivíduos, não apenas damos exemplos do que se entende pelos diferentes comportamentos de (a) seguir uma regra e de (b) ser guiado 
pelas contingências ambientais, mas também estamos apresentando duas diferentes hipóteses descritivas de seu comportamento. ${ }^{9}$ Por ora, não estamos recorrendo a nenhuma teoria, nem dando nenhuma explicação para os diferentes comportamentos desses indivíduos. Poderíamos aqui perguntar se a própria distinção entre os comportamentos de seguir uma regra ou guiar-se pelas contingências não seria um elemento de uma teoria que estamos utilizando. Mas não é, e é fácil ver que se trata apenas de uma hipótese descritiva, hipótese que nos permite comparar os dois cursos de ação daqueles dois indivíduos do exemplo acima. Isso só fica claro quando procuramos recapitular o que ocorreu (ou ocorreria) em termos puramente observacionais.

O curso de ação do visitante foi o seguinte: ele chega à cidade, parece hesitar em tomar uma rua ou outra, aborda um passante (o habitante local), fala com ele; esse responde (talvez gesticule, apontando o caminho); o visitante toma determinada rua, dirige-se para determinado local, pelo caminho, às vezes, consultando as redondezas etc. Suponhamos agora que o habitante local se dirija logo depois para o mesmo endereço, Esse habitante caminha pelas ruas e simplesmente chega a determinado local.

É óbvio que, em certo sentido, o comportamento do visitante é mais complexo que aquele do habitante. As descrições de seus cursos de ação já mostram uma diferença importante. Não faria diferença termos ouvido ou não o que eles disseram, pois isso apenas teria acrescentado mais elementos à nossa descrição do comportamento do visitante, e tornaria mais plausível para nós a hipótese (descritiva) de que ele não conhece a cidade e de que está pedindo informação. Levantaríamos com mais razão a mesma hipótese de que ele não conhece a cidade e que pede informação sobre como chegar a determinado endereço; mas isso ainda seria apenas uma hipótese para podermos descrever de forma razoável seu comportamento. Podemos dizer então que não há uma melhor descrição daquilo que ele faz; mas isso não é mais do que uma mera descrição.

Para resumir a descrição, dizemos que o visitante seguiu uma regra que o habitante local the forneceu; dizemos que ele chegou aonde queria porque seguiu as instruções que recebeu. Tais instruções funcionaram como regra de conduta, como dissemos, e tal conduta foi bem sucedida quanto à finalidade pretendida. As instruções que recebeu (a regra que o visitante seguiu) é um elemento hipotético que acrescentamos a nossa descrição. Não há nada de teórico nisso, nem explicação alguma, no sentido que queremos dar ao termo, porque estamos tomando as palavras "informação" e "regra" em seu sentido corrente. E, do mesmo modo, não há qualquer recurso a teorias ao dizermos que o habitante local foi para o mesmo endereço porque conhece o caminho. Também estamos tomando o verbo "conhecer" no mesmo sentido usual. E aqui temos também apenas uma hipótese meramente descritiva de seu comportamento.

Principia 14(2): 279-308 (2010). 
Quando é que passaríamos então, em casos de comportamentos como esses, a formular hipóteses explicativas? A resposta a esta altura é um tanto óbvia: as hipóteses explicativas correspondentes devem nos dizer o que é uma regra e o que é conhecimento. É preciso conferir um significado especial — derivado de teorias — aos termos "regra" e "conhecimento" para que apresentemos hipóteses explicativas. ${ }^{10}$

Não estamos argumentando que haja uma separação sempre nítida e definitiva entre hipóteses descritivas e hipóteses explicativas, tal como já mencionamos. A separação entre esses tipos de hipóteses depende também, obviamente, de como entendemos o que é uma teoria. E a separação entre teoria e observação, como sabemos, não é um problema de fácil solução na epistemologia. Basta lembrarmos as discussões entre Popper e os positivistas lógicos, de um lado, e aquelas entre Quine e os mesmos positivistas lógicos, de outro. ${ }^{11}$ Mas, de qualquer forma, em cada contexto de determinada comunidade epistêmica (e de falantes de determinada língua, como diria Quine), temos uma distinção entre o que seria ou não uma hipótese descritiva e o que seria então uma hipótese explicativa. Por isso dissemos acima que o que permite afirmar que aquelas narrativas dos cursos de ação dos dois indivíduos do exemplo são apenas hipóteses descritivas é o fato de que os termos "regra" e "conhecimento" foram tomados no sentido comum - o sentido que tais termos possuem para nossa comunidade epistêmica, o sentido no qual utilizamos essas palavras ordinariamente.

Ao tentarmos explicar o que é seguir uma regra e ao tentarmos então aumentarmos nosso entendimento do comportamento daquele visitante é que passamos para o nível teórico; é quando podemos oferecer hipóteses explicativas. Tal explicação, em princípio, poderia nos conduzir mesmo a desfazer a distinção entre os comportamentos de seguir uma regra e de guiar-se pelas contingências. Uma forma teórica de fazer isso consistiria, por exemplo, adotando uma perspectiva cognitivista (ou então intelectualista tradicional), em dizer que ambos os indivíduos fazem o que fazem em virtude de determinadas representações mentais que possuem. $O$ habitante daquela cidade possuiria uma espécie de mapa mental que guiaria seu caminho, e o visitante, ao receber a informação que lhe foi dada, passaria a ter o mesmo tipo de mapa mental, que também iria guiar seu caminho. Portanto, ambos os comportamentos seriam diferentes apenas na aparência, ou melhor, nas diferentes descrições que fazemos deles. Mas eles seriam, segundo tal explicação, em essência, o mesmo comportamento. Aqui temos claramente uma hipótese teórica (ou explicativa) no sentido em que estamos empregando esses termos. O que se alega não é óbvio e nem depende apenas do sentido comum dos termos, nem de uma mera narrativa dos acontecimentos aparentes.

Uma das características básicas das hipóteses explicativas, isto é, daquelas hipóteses derivadas de teorias científicas (ou mesmo pseudocientíficas) é que elas se distanciam do senso comum e das aparências. Segundo nossas hipóteses descritivas, 
os comportamentos dos dois indivíduos do exemplo acima eram claramente diferentes. Segundo a hipótese explicativa suposta no parágrafo anterior, trata-se do mesmo comportamento, contrariamente às aparências. Essa hipótese contraria as aparências e o uso comum dos termos porque recorre a uma teoria, nesse caso, a uma conjectura cognitivista (mentalista). Aqui chegamos a um ponto importante de nossa discussão principal, um ponto que permite avançar em nosso entendimento das diferenças entre a abordagem cognitivista (ou mentalista e intelectualista tradicional) e a abordagem behaviorista. ${ }^{12}$

Muitas vezes, mesmo na literatura especializada (em epistemologia e em filosofia da mente), opõem-se as abordagens mentalista (cognitivista e intelectualista) e behaviorista, como se uma negasse completamente o que a outra pretende afirmar. Um exame criterioso do que está em questão, desde logo, nos leva a desfazer enganos lamentáveis e a salvar a reputação de diversos autores. ${ }^{13}$

Em primeiro lugar, começando pelo que talvez seja mais fácil, não se pode dizer que um mentalista (um cognitivista de hoje, por exemplo) negue que as circunstâncias nas quais um indivíduo humano é colocado não façam diferença para aquilo que ele possui em termos de representação mental. É claro que o ambiente é uma fonte de informação e que pode acarretar modificações importantes na estrutura cognitiva do indivíduo (digamos assim, para utilizarmos uma expressão mais geral). As abordagens de Simon (1996) e de Hutchins (1996) ilustram bem o papel crucial do ambiente na análise da cognição. A questão para o cognitivista em geral - e nesse caso, a nosso ver, Simon e Hutchins não seriam representativos da maior parte dessa tradição ou perspectiva, mas, em relação à maioria, tomariam uma postura heterodoxa - é se não haveria estruturas ou mecanismos cognitivos mais básicos que não são adquiridos pela exposição do indivíduo às circunstâncias nas quais ele é colocado, mas que teriam de já estar presentes em sua mente para que ele possa tirar proveito, por assim dizer, de tal experiência de ser exposto a determinadas contingências ambientais. ${ }^{14}$

Do lado oposto, um adepto de uma abordagem behaviorista não pode negar que o indivíduo exposto a determinadas contingências seja modificado, que ele já tenha de possuir determinada capacidade de ser modificado pelas contingências antes de ser a eles exposto e que tal modificação possa ter efeitos duradouros - talvez mesmo permanentes. A questão para o adepto de uma estratégia behaviorista, por sua vez, é se as contingências ambientais não seriam mais determinantes sobre aquilo que um indivíduo faz do que quaisquer características (inatas ou adquiridas) que ele possa possuir, isto é, seu aparato biológico e sua história. É claro que o behaviorista admite que há características inatas (e mesmo relativas à espécie biológica) que os indivíduos possuem. Por exemplo, elas fazem diferença na determinação daquilo que é estímulo e daquilo que é premiador ou punitivo (isto é, reforçador) para cada indivíduo (ou espécie animal). Do mesmo modo, a história de cada indivíduo faz 
alguma diferença, diferença essa que não é pequena em alguns casos. Todas essas questões foram discutidas por Skinner e outros behavioristas, mesmo estando eles mais interessados no poder das variáveis ambientais sobre o comportamento atual e futuro do indivíduo do que em suas características, nesse sentido, inatas.

Onde estaria então a diferença entre um mentalista e um behaviorista? Ora, uma forma fácil de responder a isso seria dizer que o mentalista se interessaria por compreender aquilo que, inato ou adquirido, se encontra dentro da pele dos indivíduos, para utilizarmos uma famosa expressão de Skinner. E o behaviorista, por sua vez, se interessaria por compreender aquilo que está no ambiente, isto é, fora da fronteira biológica natural que é a pele. Essa é uma solução muito simplificadora, que apenas adia um diálogo mais produtivo entre as duas perspectivas. O mentalista e o behaviorista não pretendem produzir teorias e ciências divorciadas, destinadas a explicar fenômenos completamente diversos. ${ }^{15}$ Ambos estão interessados em explicar o comportamento humano e, mais especificamente também, a cognição e o conhecimento. E promover o entendimento entre as duas perspectivas é uma tarefa que não pode ser negligenciada, embora seja árdua. Ela é talvez crucial para o futuro da psicologia e da epistemologia, embora requeira a elaboração de uma teoria de unificação de grande envergadura, o que não parece estar em nosso horizonte de realização próxima. $^{16}$

Voltemos ao caso do comportamento de seguir uma regra. É um fato inegável (uma hipótese descritiva, podemos dizer) que os indivíduos humanos são capazes de seguir regras e que isso faz diferença mesmo em relação às circunstâncias nas quais eles são colocados. E isso é reconhecido pelo próprio Skinner, pois, embora seja diferente do comportamento dirigido por variáveis ambientais, o comportamento de seguir uma regra pode ser vantajoso, na medida em que o indivíduo que segue a regra não precisa ser exposto às mesmas contingências que originaram a própria regra, o que, por vezes, nem é possível.

Além disso, aqui, ainda no nível das hipóteses e questões meramente descritivas, o que devemos nos perguntar é se o comportamento de seguir regras em geral é resultado de seguir uma regra - uma metarregra, digamos, ou uma regra de segunda ordem. A resposta de Skinner (1969) para essa questão, como mencionamos, é exatamente que adquirimos o comportamento de seguir regras quando somos expostos a determinadas contingências, e que, em última instância, o comportamento guiado pelas contingências tem precedência sobre aquele de seguir regras. Em outras palavras, mesmo que sejamos capazes de ir para níveis superiores na criação de metarregras (o que provavelmente é o que ocorre, por exemplo, no caso das gramáticas das línguas que falamos e aprendermos), isso não prossegue indefinidamente, mas termina em alguma contingência. Pode haver regras formuladas, de diversos tipos, mas a questão crucial, segundo Skinner, é o que nos faria em geral seguir regras. ${ }^{17}$ Aqui, um cognitivista daria uma resposta diferente — como, de fato, Chomsky deu — 
ao dizer que esse processo termina em algo inato que, por sua vez, também funciona como regra. ${ }^{18}$

Para uma investigação sobre a cognição e o conhecimento, que é o que nos interessa principalmente, uma regra é algo semelhante a uma crença. Isto é, uma regra é uma peça de conhecimento, digamos, um item de conhecimento. O indivíduo que segue uma regra se comporta assim em virtude de determinado conhecimento (ou informação) que possui. Estamos aqui empregando o termo "conhecimento" para denotar quaisquer coisas tradicionalmente atribuídas ao sujeito cognoscente, como: opiniões, ideias, crenças, noções, conceitos etc., e também, portanto, informações e regras. Mas, assim como só faz sentido atribuir uma crença a determinado indivíduo, como antes vimos, se ele apresenta uma modificação de comportamento, da mesma forma, só podemos atribuir a determinado indivíduo a posse de uma regra se houver uma base para isso em seu comportamento manifesto.

À primeira vista, haveria dois casos aqui. Primeiro, podemos atribuir a certo indivíduo o comportamento de seguir uma regra se ele deixa de se comportar da forma habitual em determinado tipo de circunstância. No caso do exemplo do visitante, é de esperar que uma pessoa que queira ir a determinado endereço em uma cidade aja como agiu o habitante local, e não que peça informação. É por isso que, nesse caso, podemos dizer que a informação que o visitante recebeu funciona como regra para ele. Pois o caso ordinário - similar ao do morador da cidade - seria o de simplesmente dirigir-se para o endereço pretendido.

Segundo, o comportamento de seguir uma regra também pode se tornar habitual. Mas, nesse caso, é preciso que haja circunstâncias que nos façam esperar um curso de ação diferente daquele que esperaríamos do agente em circunstâncias ordinárias. Para ainda explorarmos o mesmo exemplo, em circunstâncias normais, o habitante da cidade que deu a informação ao visitante não se dirigiria para o mesmo endereço logo em seguida. Contudo, se isso ocorrer, podemos levantar a hipótese de que esse morador está seguindo, por exemplo, uma regra que manda vigiar os forasteiros pela cidade. Se esse não for um comportamento recorrente das pessoas que moram na referida cidade, então a hipótese de que o morador segue uma regra não faz sentido.

Em todos esses casos, temos apenas hipóteses descritivas, obviamente. E, além disso, o que os dois tipos de comportamento de seguir uma regra nos dão é uma espécie de relação entre determinado padrão de comportamento e a quebra dele. A relação entre um padrão e sua quebra se inverte nos dois tipos de casos. Em um, o padrão, por assim dizer, é o comportamento esperado. No segundo, o padrão está incorporado na regra seguida. Em ambos os casos, contudo, há um padrão de comportamento, seja ele esperado ou inesperado (em um primeiro momento, nesse caso, e depois, por assim dizer, descoberto — ou pelo menos indicado pela hipótese levantada).

Principia 14(2): 279-308 (2010). 
Resumindo o que dissemos acima, do ponto de vista comportamental, seguir uma regra é um tipo de comportamento — ou padrão — que se apresenta em situações similares. No primeiro dos dois casos acima apontados, e seguindo mais uma vez o mesmo exemplo de antes, se o comportamento esperado de alguém que chega a uma cidade é o de dirigir-se para o endereço desejado; se a pessoa não faz isso, mas, ao contrário, pede informação, então podemos dizer que ela segue uma regra segundo a qual, se chegamos a uma cidade desconhecida, devemos pedir informação. O padrão de comportamento se revela quando, por meio de hipóteses descritivas, ampliamos o escopo de análise, por assim dizer, e descrevemos um contexto mais amplo de ação, contrapondo o comportamento observado com outro, que era esperado e que não se deu, de tal forma que somos levados à formulação da hipótese de que o indivíduo segue uma regra. Esquematicamente, teríamos então os seguintes passos:

(1) o comportamento esperado (segundo outro padrão ou regra conhecida);

(2) o comportamento novo (inesperado ou anômalo);

(3) a regra que incorpora o novo comportamento como padrão. ${ }^{19}$

No segundo dos casos de comportamento de seguir regras, aquele que seria exibido pelo habitante local, teríamos o seguinte: se o comportamento esperado de alguém que dá informação a um visitante é o de seguir com seus afazeres, e se a pessoa que dá a informação, ao contrário, segue o visitante (indo para o mesmo endereço, digamos), então podemos dizer que a pessoa segue uma regra segundo a qual, se percebermos um forasteiro, devemos segui-lo. Do mesmo modo que anteriormente, o padrão de comportamento se mostra por meio do auxílio de hipóteses descritivas e conduzindo aos mesmos passos (1)-(3) acima indicados.

Por ora, não estamos discutindo a origem das regras que possamos seguir. Para o mentalista, a regra é inata ou a priori, no sentido de que precede quaisquer circunstâncias e comportamentos que, repetindo-se, possam conduzir à implantação de um padrão de comportamento, isto é, a regra justamente. ${ }^{20}$ Para o behaviorista, é justamente essa a origem das regras, como Skinner procura mostrar. Mas, uma vez de posse de uma regra, nesse sentido, o indivíduo exibe determinado padrão de comportamento.

O importante é que esse padrão implantado de comportamento (ou inato, no caso de preferirmos adotar uma abordagem mentalista), impediria que o indivíduo se comportasse em função das variáveis ambientais próximas, isto é, daquelas que indicariam outro comportamento esperado nas circunstâncias conhecidas. Em outras palavras, um indivíduo segue uma regra quando age de forma diferente daquela que deveria agir em determinada circunstância caso fosse guiado por contingências ambientais (previamente conhecidas).

No caso do visitante do exemplo que temos analisado, em resumo, podemos dizer que ele seguiu uma regra porque não chegou ao endereço pretendido guiado 
por contingências ambientais ordinárias, mas pela instrução que o habitante local lhe deu. Contudo, obviamente, se considerarmos que a instrução dada pelo habitante também faz parte das contingências ambientais, então o visitante não exibiu um comportamento assimilável àquele de seguir uma regra. Mas isso só mostra o caráter precário desse tipo de hipótese que fazemos para compreender o que as pessoas fazem. De fato, não estamos sustentando que haja uma separação radical entre as duas formas de comportamento, nem que não haja casos limítrofes. Apenas uma teoria mais elaborada e que levantasse hipóteses explicativas poderia eliminar completamente os casos limítrofes. Em última instância, é claro que é a descrição que fazemos de uma situação de ação que separa os comportamentos de seguir uma regra e de ser guiado pelas contingências ambientais. ${ }^{21}$

Outros exemplos comuns ajudam a esclarecer esse ponto. O preceito cristão de dar a outra face é uma regra desse tipo. Na vida comum, em circunstâncias ordinárias e talvez sem grande importância, temos instanciações de uma regra semelhante. O empregado que não reage a um insulto de seu patrão está provavelmente seguindo uma regra. O vizinho que continua a cumprimentar outro, que nunca lhe responde, também está provavelmente seguindo uma regra. Nesses casos, assim como em outros, devemos dizer que provavelmente tais pessoas seguem regras porque estamos apenas no nível das hipóteses descritivas. Simplificando um pouco, podemos dizer que, diante de um insulto, a reação normal, digamos (isto é, aquela ditada pelas contingências), é a de insultar também. Mas se o empregado não responde ao insulto de seu patrão é porque ele visa a um objetivo mais remoto, isto é, manter seu emprego. Do mesmo modo, se certo indivíduo continua a cumprimentar o vizinho que o ignora, é porque ele pode pensar que, a qualquer momento, poderá precisar da ajuda daquele vizinho, e, assim, o melhor é aturá-lo do que, diante da descortesia, insultá-lo ou também ignorá-lo.

O que essa análise nos revela de mais interessante quanto ao comportamento provável de seguir uma regra é que o indivíduo se furta, digamos, às contingências ou, melhor dizendo, não age em função das variáveis ambientais próximas ou imediatas porque ele age em função de objetivos mais remotos - e esse é um aspecto do problema que não foi considerado por Skinner com profundidade. ${ }^{22}$ Esse problema tem sido muito discutido por economistas e psicólogos com relação ao contraste entre os comportamentos de escolher uma premiação menor a curto prazo ou uma premiação maior a longo prazo. Discute-se o que seria mais racional. Em uma primeira aproximação, podemos dizer que não haveria por que avaliar em termos de racionalidade esses diferentes comportamentos, já que eles seriam comportamentos de tipos diferentes. Antes de compará-los em termos de maior ou menor racionalidade, temos de entender a diferença mais básica entre eles.

Uma hipótese descritiva para entendermos esses diferentes comportamentos econômicos seria dizer que o indivíduo que escolhe a menor premiação a curto prazo 
age em função das contingências ambientais próximas e que aquele que escolhe a maior premiação a longo prazo segue uma regra. É porque segue uma regra que ele, assim como os indivíduos nos outros exemplos acima, pode escapar às contingências ambientais.

Alguns behavioristas, ao contrário de Skinner, dizem que tal indivíduo age simplesmente em função de contingências mais remotas, como faz Howard Rachlin (1984), já mencionado. Mas Rachlin, por sua vez, não explica satisfatoriamente como as circunstâncias mais remotas podem controlar o comportamento de um indivíduo. A longo prazo (que é o que Rachlin reivindica para uma análise adequada do comportamento), podemos entender por que certo indivíduo escolhe a maior premiação, por que não responde ao insulto de seu patrão, por que continua a cumprimentar o vizinho mal-humorado etc.; mas também podemos compreender casos mais estranhos, como, por exemplo, aquele de um indivíduo que escolhe receber uma menor premiação a longo prazo. Ele também estariaseguindo uma regra, i.e., aparentemente, escapando do controle de variáveis ambientais mais próximas e mesmo mais remotas.

Contudo, nesse caso, um behaviorista como Rachlin teria de dizer que tal indivíduo tem seu comportamento controlado por contingências mais remotas ainda. Ora, a hipótese de que ele segue uma regra é uma hipótese descritiva muito melhor, obviamente. A hipótese descritiva de que, ao seguir uma regra, em geral, os indivíduos escapam às circunstâncias presentes, e podem então agir independentemente delas, é uma hipótese descritiva mais simples. A questão (agora teórica) difícil é a de como entender exatamente o que seria uma regra. E aqui os cognitivistas estão mais à vontade para responder do que os behavioristas. Mas também nesse ponto podemos permanecer apenas no nível de hipóteses descritivas, que é o que pretendemos.

Voltando a um tema que já comentamos, podemos conceder ao behaviorista um ponto, a saber, que nos indivíduos é implantado o comportamento de seguir regras em função de contingências ambientais. Mas isso não nos dispensaria de entender melhor o comportamento de seguir regras em contraste com aquele de guiar-se pelas contingências diretamente. Recapitulando, conservemos então a hipótese (também descritiva) de que agir segundo uma regra é agir contrariamente às variáveis ambientais próximas.

A esta altura, não seria uma trivialidade dizermos que a vida social é cheia de regras, como já tem sido tão enfatizado por tantos autores. Pois o sentido que podemos dar a essa afirmação (de forma a tirá-la da trivialidade) é que, quando os indivíduos agem no meio social seguindo regras - em vez de se levarem pelas circunstâncias —, eles estão de posse de algum conhecimento. Por exemplo, o psicoterapeuta que não reage a um insulto de seu paciente não faz isso apenas porque não quer perder o cliente e a remuneração que ele lhe traz, mas porque sabe (ou acha, ou crê) que o cliente apenas transferiu para ele a agressividade que não pode dirigir à pessoa para quem deveria dirigi-la.

Principia 14(2): 279-308 (2010). 
Esse exemplo deixa claro mais que os anteriores que seguir uma regra é estar de posse de determinado conhecimento (ou informação, se preferirmos). ${ }^{23}$ Esse é um aspecto cognitivista da questão que não podemos evitar. Conscientemente ou não, o indivíduo que não responde da forma esperada às circunstâncias ambientais, aquele que, por assim dizer, parece escapar ao determinismo causal do meio e das circunstâncias em que se encontra, é o indivíduo que está de posse de certo conhecimento. Em outras palavras, o comportamento inesperado de não se deixar levar pelas circunstâncias, caso em que dizemos que o indivíduo está seguindo uma regra, motiva a atribuição a ele de algum conhecimento. Além disso, se não houver uma diferença observável de comportamento, não há por que atribuir a determinado indivíduo algum conhecimento. Ora, comportar-se de forma inesperada, dadas certas contingências, é motivo suficiente para lhe atribuir então algum conhecimento.

Entretanto, é preciso voltarmos a um dos aspectos relevantes do comportamento de seguir uma regra, a saber, que tal comportamento exibe um padrão. Dar a outra face, para o cristão, é um padrão de comportamento. Nos exemplos acima mencionados, se não houver repetição e se, por diversas vezes, não observarmos que o indivíduo aparentemente espada às contingências ambientais presentes, não podemos dizer que ele segue uma regra. Em outras palavras, se o cristão oferecesse a outra face apenas uma vez na vida, não poderíamos dizer que ele segue esse princípio ou regra. De um ponto de vista estritamente comportamental, se tomarmos como normal o comportamento que é regido por contingências ambientais, então o comportamento de seguir uma regra é, por assim dizer, um comportamento anômalo recorrente. Mas, na medida em que pudermos entender qual é a regra que está sendo seguida e conectá-la com uma finalidade mais remota da ação do indivíduo, então tal comportamento deixa de ser anômalo. Contudo, assim descrito, ele surge como comportamento de um tipo diferente.

\section{O conhecimento como hipótese descritiva}

A esta altura, também não seria trivial dizermos que não há como negar que um indivíduo que segue uma regra possui algum conhecimento. O conhecimento que ele possui pode ser uma mera hipótese, uma conjectura, uma crença etc., como nos casos do psicoterapeuta e do empregado, assim como nos outros casos acima mencionados.

Por exemplo, o empregado que não responde ao insulto do patrão age assim porque acredita que, agindo dessa forma, vai conservar seu emprego. Contudo, por outros motivos, ele poderá ser demitido no dia seguinte. Portanto, ele segue uma regra por ter a crença de que vai conservar seu emprego. Apenas ampliar no tempo nossa análise do comportamento desse indivíduo, nesse caso, não ajudaria muito a 
entender o que ele faz, obviamente. Pois podemos dizer que ele age em função de contingências mais remotas porque possui determinada crença. Logo, é a atribuição de crença que mais ajuda a entender o que ele faz - e não o fato de dilatarmos o tempo de observação de seu comportamento. ${ }^{24}$

O psicoterapeuta também pode estar errado em sua crença de que o paciente apenas transfere para ele a agressividade que deveria dirigir a outra pessoa. Mas entendemos sua falta de reação quando lhe atribuímos tal crença e descrevemos seu comportamento como o de seguir uma regra profissional.

De forma similar, no caso do comportamento econômico, aquele que escolhe a recompensa maior a longo prazo faz isso porque acredita que haverá uma recompensa no futuro. A falência de certas instituições financeiras, repetida e lamentavelmente, tem denunciado essas falsas crenças. Mas também entendemos o comportamento das pessoas que aplicam seu dinheiro nessas instituições.

De uma forma mais geral, a atribuição de conhecimento a qualquer indivíduo é uma hipótese descritiva para entendermos uma parte de seu comportamento, inclusive seu comportamento verbal. Mas essa atribuição de conhecimento só tem sentido empírico quando é feita diante de um comportamento anômalo e recorrente (ou discrepante, ou inesperado, em determinadas circunstâncias). No curso normal ou ordinário dos acontecimentos sociais, isto é, do agir comum das pessoas, não haveria por que lhes atribuir nenhum conhecimento. Essa afirmação que, à primeira vista, pareceria tão contra-intuitiva, de fato, uma vez bem comentada, também parecerá até mesmo um tanto trivial - e por isso mesmo, aceitável.

Nosso estranhamento inicial com tal afirmação decorre do fato de que estamos acostumados a atribuir conhecimentos (crenças, por exemplo) às pessoas o tempo todo para podermos entender o que elas fazem. Mas nos esquecemos das circunstâncias mais típicas e cruciais nas quais é realmente necessário atribuir algum conhecimento a alguém, sendo que, em muitas outras ocasiões, poderíamos entender o que as pessoas fazem sem atribuir a elas qualquer conhecimento, mas, por exemplo, atribuindo-lhes apenas certos hábitos - desde que façamos a distinção entre hábito e crença e não atribuamos aos hábitos nenhum componente cognitivo relevante ou determinante. Em grande medida, é nossa herança intelectualista e mentalista que nos induz, mesmo quando não é necessário, a sempre atribuirmos conhecimentos (crenças ou opiniões) às pessoas. De fato, a atribuição de crenças ou opiniões se dá ordinariamente naquelas circunstâncias em que, justamente, não entendemos bem o que uma pessoa faz.

A atribuição de conhecimento nos casos do comportamento de seguir regras que estivemos comentando antes é pertinente naquelas circunstâncias indicadas, na seção anterior, pelas etapas (1)-(3). Assim, retomando aquele esquema de forma mais abrangente, temos as circunstâncias apropriadas para a atribuição de certo conhecimento a um agente:

Principia 14(2): 279-308 (2010). 
(A) há um padrão esperado de comportamento, dada a situação observada;

(B) essa expectativa não é contemplada, pois o agente faz outra coisa;

(C) é possível levantar uma hipótese descritiva segundo a qual a ação do agente se deu em virtude de determinada crença (ou informação, ou conhecimento etc.), isto é, em virtude de seguir ele uma regra.

Com isso, deixamos de descrever o comportamento do agente com base apenas nas circunstâncias (ou variáveis ambientais), e descrevemos seu comportamento com base em uma situação mais ampla, situação essa que inclui a atribuição ao agente de algum conhecimento. Essa hipótese descritiva de atribuição de conhecimento é passível de confirmação — ou, ao contrário, de infirmação — em situações semelhantes.

O conhecimento que atribuímos então a um agente, nesses termos, é uma mera hipótese descritiva que ainda não está ligada a qualquer explicação do comportamento dessa pessoa. A questão crucial à qual o debate entre behavioristas e cognitivistas poderia nos conduzir — aparentemente, de forma inevitável — seria aquela sobre o estatuto teórico da regra (ou do conhecimento) que, em tais casos, atribuímos ao agente. Mas essa questão, como já dissemos, se coloca apenas quando passamos do nível das hipóteses descritivas para aquele das hipóteses explicativas, pois então temos de apresentar uma teoria.

Entretanto, o que desejamos é apenas permanecer no nível de hipóteses descritivas do comportamento. E, nesse caso, a atribuição de conhecimento a um agente não transforma uma análise inicialmente comportamental da ação em uma análise mentalista. Não faria sentido nesse nível de descrição hipotética do comportamento do agente perguntar se a regra que ele segue está dentro dele, ou em sua cabeça, ou em seu cérebro etc. Essa, mais uma vez, seria uma pergunta a ser respondida por meio de hipóteses explicativas, tal como uma teoria cognitivista nos levaria a fazer, ou, em vez disso, como uma postura behaviorista nos impediria de fazer.

Assim sendo, o que estamos dizendo é que a atribuição de conhecimento a um agente cujo comportamento mudou é uma hipótese descritiva e meramente comportamental. Por isso é mais apropriado dizermos que o agente em questão segue uma regra, em vez de dizer que ele possui determinado conhecimento ou crença, embora, segundo nossa análise, essas sejam formas alternativas de dizer o mesmo. Mas, quando dizemos que o agente segue uma regra, em vez de ser conduzido pelas contingências, não temos a tentação intelectual (pelo menos não tão prontamente) de passarmos para o nível das hipóteses explicativas - sejam elas behavioristas, sejam cognitivistas. Por isso podemos dizer que nossa análise aqui não é propriamente behaviorista, mas, antes, meramente ambientalista, no sentido descritivo (e não explicativo).

O ponto central da presente análise do conhecimento humano é a ideia de que

Principia 14(2): 279-308 (2010). 
a atribuição de conhecimentos a um agente deve ser feita — porque ordinariamente assim é - quando tal pessoa apresenta uma modificação relevante de comportamento. Trata-se de uma hipótese descritiva que faz parte de nossa investigação sobre o comportamento daquela pessoa, investigação que se destina a nos conduzir ao entendimento do que ela faz de inesperado. Por exemplo, se na casa de certa pessoa que nos convida pela primeira vez encontrarmos os objetos todos fora do lugar, isso não deverá despertar nossa curiosidade. Mas suponhamos que vamos visitar um amigo que sempre teve tudo muito ordenado em sua casa e que, naquele dia, a casa está com os objetos todos fora do lugar e de maneira caótica. Nesse caso, podemos simplesmente pensar que aquele indivíduo esteve procurando alguma coisa pela casa com muita pressa e necessidade.

Contudo, suponhamos agora que os objetos estão todos fora dos lugares habituais, mas de forma ordenada. Por exemplo, os objetos de cozinha estão no banheiro; os do banheiro, no escritório; os desse cômodo, num dos quartos, e assim por diante. E suponhamos também que aquele indivíduo, não demonstrando nenhuma anormalidade da fala ou de comportamento em geral, mantenha tais objetos nessa nova disposição de propósito e com toda ordem, como antes fazia em sua casa. Se ele demonstrasse alguma alteração relevante em seu comportamento verbal (por exemplo, dizendo coisas estranhas) ou outros distúrbios de comportamento, a melhor hipótese, sem dúvida, seria aquela de que ele estaria com algum problema mental.

Entretanto, se esse não fosse o caso, se o indivíduo se comportasse de maneira perfeitamente normal, se falasse normalmente como antes etc., então, obviamente, o mais razoável seria perguntar-lhe por que os objetos da casa estão todos em cômodos trocados. E suponhamos, por mais estranho que possa ser, que o indivíduo diga que trocou os objetos de lugar porque está praticando um novo tipo de terapia - qualquer que seja e por mais estranha que possa parecer. Ora, nossa hipótese descritiva então só poderá ser a de que esse indivíduo acredita que a disposição dos objetos numa casa afeta o comportamento das pessoas, de que uma troca sistemática poderá produzir algum efeito, qualquer que seja ele, e assim por diante. A esse indivíduo não apenas atribuímos determinada crença, mas também pensamos que ele age seguindo regras da doutrina (ou terapia) que adotou.

Um famoso seriado de TV de décadas atrás mostrava uma família do interior dos Estados Unidos que, tendo descoberto petróleo em suas terras, enriqueceu e mudou-se para Beverly Hills, indo morar numa mansão. As pessoas dessa família não conheciam os equipamentos da casa - peças de banheiro, por exemplo - e outras coisas. E por isso faziam um uso muito incomum desses objetos, como, por exemplo, utilizar uma banheira de mármore para criar peixes, o vaso sanitário para cultivar plantas, e assim por diante. Esse tipo de coisa também acontece na vida real, como por vezes se diz que ocorre com pessoas de baixa renda de irem morar em casas de conjuntos habitacionais novos, havendo nas casas equipamentos com os 
quais essas pessoas nunca tinham lidado, e que elas fazem um uso incomum deles. O uso que é feito desses objetos é muitas vezes comparável ao do caso do seriado de TV.

Suponhamos então, contrariamente ao que ocorria com o indivíduo do exemplo anterior, que uma pessoa morando em uma casa onde há objetos que ela não conhece, comece a utilizá-los da forma que lhe parece apropriada e que essa forma seja diferente daquela que é comum para as pessoas que conhecem tais objetos. Suponhamos que Petúnia plante margaridas no vaso sanitário, por exemplo. É óbvio que, em primeiro lugar, vamos dizer que ela não sabe que aquilo é um vaso sanitário e que ela acredita que aquilo é um vaso de plantas. É o comportamento desviante de Petúnia que nos leva a atribuir a ela determinada crença - e a não lhe atribuir, em contrapartida, o conhecimento do uso normal daquele equipamento sanitário.

E suponhamos que, ao contrário, o pai de Petúnia entre em cena e diga que ela não deve plantar margaridas no vaso sanitário, pois aquilo é para outro uso, e assim por diante. Ora, a ele atribuímos agora o conhecimento do uso habitual daquele objeto. Nesse caso, o comportamento dele é esperado para nós, mas contrasta com aquele de Petúnia, e por isso pede uma atribuição de crença ou conhecimento. Se nada disso ocorresse com essas pessoas, e se elas simplesmente utilizassem o vaso sanitário como todos nós, não haveria necessidade de levantar as hipóteses descritivas que levantamos a respeito de suas crenças.

A conclusão mais importante dessas análises é que são as modificações de comportamento que nos conduzem a levantar as hipóteses descritivas segundo as quais as pessoas possuem determinados conhecimentos. ${ }^{25}$ É claro que, em última instância então, num mundo em que não houvesse comportamentos inesperados, não haveria qualquer atribuição de crença ou conhecimento. Para nós, em contraste com nosso mundo real, tal mundo seria um mundo de autômatos, indivíduos programados e funcionando perfeitamente, um mundo de zumbis perfeitos - indivíduos que agem não em virtude de crenças, mas que simplesmente respondem convenientemente a estímulos ambientais. Claro que a tais autômatos não atribuiríamos qualquer conhecimento, a não ser num sentido impróprio, isto é, da programação que eles possuiriam. Mas essa programação que a eles atribuiríamos seria o correlato das crenças (ou conhecimentos, ou estados cognitivos e intencionais) que atribuímos aos seres humanos comuns. Ela seria também uma hipótese descritiva para entendermos o contraste entre nosso comportamento comum e o daqueles autômatos.

Assim, são sempre as modificações de comportamento — ou inesperadas, ou contrastantes - que nos despertam para as investigações que fazemos a respeito de como as pessoas agem, o que nos leva, em determinado momento, a atribuirmos a elas determinados conhecimentos. Assim sendo, mesmo que entendido depois em termos puramente cognitivistas ou mentalistas, o conhecimento é uma noção em primeiro lugar comportamental. Pois, em suma, são as modificações de comportamento 
que pedem a atribuição aos agentes humanos de determinados estados cognitivos, como crenças, concepções, teorias ou ideias.

Tem sido também um argumento comum dizer que com os novos recursos tecnológicos, como os aparelhos de ressonância magnética, poderíamos mapear as áreas do cérebro e associá-las a determinados comportamentos, inclusive o comportamento verbal, e a supostos estados cognitivos relatados pelo indivíduo examinado em tais aparelhos. Essas observações, contudo, só podem ser interpretadas à luz de episódios do comportamento manifesto dos indivíduos ou pelo menos de seu comportamento verbal. Se colocarmos uma pessoa em um desses aparelhos e lhe pedirmos para pensar numa rosa, observando então que determinada área do cérebro apresenta uma modificação, é o comportamento verbal dessa pessoa (de dizer que pensou numa rosa) que nos permite interpretar o resultado apresentado pelo aparelho. Além disso, relacionar essa experiência com algum suposto estado cognitivo (que não é meramente o estado neurofisiológico do cérebro) é um segundo passo, que damos agora com o auxílio de uma hipótese suplementar. Nesse caso específico, a correlação entre o comportamento verbal do indivíduo e aquele resultado do aparelho é apenas descritiva e, nesse mesmo contexto, a hipótese cognitivista que a esses dois elementos correlaciona um estado cognitivo é claramente uma hipótese explicativa e, aliás, supérflua. Mas, em suma, em todas essas correlações, sempre existe um comportamento observado, que é o ponto de partida da investigação, seja com o objetivo de interpretar estados cerebrais (observados em aparelhos), seja para postular estruturas cognitivas e lhes dar interpretação empírica ou observacional.

\section{Crenças que não acarretam modificações de comportamento}

Se os comentários das seções precedentes forem pertinentes, então devemos enfrentar a segunda das duas questões principais colocadas desde início, a saber, se há ou não crenças que não levam o agente a ter modificações de comportamento. À primeira vista, a resposta um tanto óbvia seria, do ponto de vista aqui adotado, a de que não pode haver tais crenças, isto é, que não haveria sentido em levantar a hipótese descritiva de que determinado agente possui uma crença que não acarrete mudança em seu comportamento.

Enquanto hipótese descritiva, o conhecimento atribuído a um agente humano é parte integrante de nossa investigação sobre o comportamento desse agente. Em conformidade com a análise acima apresentada, são suas modificações de comportamento que nos conduzem a levantar tal hipótese. Portanto, trata-se de algo que faz parte de um processo de investigação no qual a noção de conhecimento desempenha papel relevante. A questão a ser enfrentada seria então reformulada da seguinte maneira: haveria circunstâncias de nossa investigação sobre a ação de sujeitos hu- 
manos nas quais deveríamos atribuir a eles crenças que não acarretam modificações de comportamento?

A atribuição de conhecimento a um agente, enquanto estratégia para entendermos seu comportamento manifesto, é, portanto, uma forma de preenche lacunas, por assim dizer, no relato que fazemos do comportamento de determinados indivíduos. Assim sendo, dizer que certo indivíduo possui uma crença é apenas uma forma de relacionar alguns episódios de seu comportamento. Além disso, na medida em que pudermos encontrar padrões de comportamento do indivíduo, poderemos também descrever certo repertório de comportamento, para utilizarmos um termo mais técnico. Em última instância, no limite, deveríamos então poder correlacionar os diversos repertórios de comportamento do indivíduo, e termos um relato, por assim dizer, completo do que ele faz. Enquanto não atingirmos tal limite, teremos descrições pelo menos cada vez mais abrangentes da ação do indivíduo. Essa é uma espécie de ideia reguladora para esse tipo de investigação.

Uma investigação bem sucedida sobre o comportamento de um indivíduo que é feita nesses termos nos daria, utilizando uma imagem comum, uma espécie de retrato do indivíduo enquanto agente - um retrato dele que seria eminentemente comportamental. Isto é, teríamos uma caracterização comportamental do indivíduo de forma a podermos mesmo prever o que ele fará em determinadas circunstâncias. Teríamos, para utilizar outra forma de falar comum nas ciências, um modelo da ação desse agente. Ora, é exatamente isso o que em geral almejamos a respeito do conhecimento que temos das outras pessoas. É também aquilo que, de forma dramatizada, encontramos nas estórias de detetives, nas quais um investigador analisa o comportamento dos suspeitos de cometer determinado crime, chegando a identificar aquele que, de fato, o perpetrou. O investigador elabora modelos de ação dos suspeitos e os testa até chegar a identificar o culpado.

Ora, na medida em que dois episódios de comportamento de um agente puderem ser conectados da forma proposta pela análise acima proposta, como dissemos, determinada crença ou conhecimento é a ele atribuída como mera hipótese descritiva. Do mesmo modo, se pudermos conectar dois repertórios de comportamento desse agente, a mesma atribuição de crença ou conhecimento é feita. Se cada atribuição de crença é um modelo parcial da ação do indivíduo, modelos mais amplos são aquilo que permitiria conectar seus repertórios de comportamento.

Por exemplo, suponhamos que determinado indivíduo siga a regra de pedir informação ao chegar a cidades que ele não conhece. E suponhamos que haja exceções em alguns casos observados de seu comportamento. Ora, será natural dizermos então que tais exceções ocorrem porque, naqueles casos, ele estava seguindo outra regra, isto é, que estava de posse de outro conhecimento. Isso poderia ocorrer, por exemplo, se o indivíduo tomasse por conhecida uma cidade desconhecida, o que, a rigor, denominaríamos um caso de erro, ou se aquela nova cidade possuísse o mesmo 
traçado urbanístico de outra já conhecida (uma informação ou conhecimento que o agente deveria ter).

Contudo, segundo nossa análise, esse tipo de ocorrência (mesmo sendo o caso do suposto erro) pode ser descrito como o de estar o indivíduo seguindo outra regra, justamente aquela que diz que não se deve pedir informação em cidades conhecidas. Mas podemos então perguntar como o indivíduo discrimina entre as situações nas quais vai seguir ou essa nova regra, ou a anterior. Aqui também há duas possibilidades: ou apontamos circunstâncias ambientais que guiam o comportamento desse indivíduo que, em função delas, vai seguir então uma ou outra das regras, ou atribuímos a ele outro conhecimento, isto é, a rigor, segundo essa forma de análise, uma espécie de metarregra, ou de regra de segunda ordem, que indica quando seguir uma ou outra das regras anteriores. E com isso integramos os modelos anteriores e menores em um modelo maior, que retrata um segmento mais amplo de seu comportamento.

Voltamos aqui a um dos pontos já mencionados, e que divide as opiniões de behavioristas e cognitivistas. Os behavioristas tenderiam a invocar contingências ambientais para explicar a mudança de uma regra para outra, enquanto que os cognitivistas tenderiam a buscar as possíveis metarregras ou regras de segunda ordem que estariam regendo o comportamento de seguir regras daquele agente. Nas duas abordagens, contudo, há sempre limites para a análise. As dificuldades metodológicas aqui estão ligadas à elaboração de modelos mais abrangentes do comportamento do indivíduo. Ou não conseguimos identificar no ambiente as variáveis em cuja dependência estaria aquele novo comportamento do agente, aparentemente, mais complexo (de mudar de uma regra para outra), ou não conseguimos formular uma metarregra a não ser postulando uma estrutura unificadora e estratificada de regras, estrutura essa que, por assim dizer, coordenaria regras de primeira ordem e regras de ordem superior.

Nesse último caso, não estaríamos mais levantando uma mera hipótese descritiva, mas uma hipótese explicativa. Uma hipótese descritiva que atribui determinado conhecimento a um agente, tal como aqui entendido, apenas preenche uma lacuna entre dois seguimentos de seu comportamento. A hipótese de uma metarregra que correlaciona dois comportamentos alternativos de seguir diferentes regras ainda pode ser uma hipótese apenas descritiva, caso ela possa ser introduzida sem o recurso a uma estrutura do tipo que mencionamos no parágrafo anterior. Se isso puder ser feito, então continuamos a atribuir ao agente uma crença ou conhecimento que acarreta modificação de comportamento. Mas caso seja preciso introduzir a hipótese de uma estrutura sem que uma metarregra seja diretamente indicada, então fugimos do âmbito das hipóteses meramente descritivas.

Isso seria equivalente ao que, na física, foi a hipótese de variáveis ocultas para explicar os eventos quânticos. ${ }^{26}$ A existência de uma estrutura de regras é uma hipótese 
explicativa que atribui ao agente conhecimentos que não acarretam modificações de comportamento. Tal estrutura apenas permitiria relacionar as regras já formuladas e prover um lugar, por assim dizer, para outras que ainda não foram formuladas. Desse modo, a hipótese (explicativa) de tal estrutura, mesmo não estando, portanto, relacionada com nenhuma modificação de conhecimento, guiaria nossa investigação na descoberta de outras possíveis regras, de forma similar ao que, na mecânica quântica, sustentavam os defensores das teorias de variáveis ocultas.

A hipótese de uma estrutura que correlaciona diversas regras e, logo, conhecimentos do agente, ainda poderia receber uma interpretação comportamental e ser, afinal, encarada apenas como mais uma hipótese descritiva no caso de procurarmos apenas correlacionar regras já conhecidas ou formuladas, isto é, conhecimentos ou crenças já atribuídos ao agente. Mas ela deixa de ser uma hipótese descritiva e passa a ser uma hipótese explicativa de viés cognitivista porque introduz também a ideia de regras ainda não conhecidas, isto é, certo conhecimento que o agente possuiria, mas que não se manifestou ainda na forma de modificações de seu comportamento.

Em outros termos, tentar construir tal estrutura hierarquizada de correlações de crenças a partir de crenças já atribuídas ao agente não conduz necessariamente ao domínio das hipóteses explicativas cognitivistas. Mas presumir que haja tal estrutura já pertence ao domínio dessas hipóteses explicativas cognitivistas, seja porque tal estrutura já é em si um conteúdo mental, digamos, seja porque a hipótese envolve a ideia da existência de outros conteúdos ainda não descobertos, mas que poderiam ser atribuídos ao agente, mesmo não se manifestando sob a forma de modificações de comportamento.

Entretanto, ainda permanece a questão de como podemos dar unidade aos repertórios de comportamento de um agente, que pressupomos ser sempre a mesma pessoa agindo nesses diversos episódios de sua ação. E aqui, mesmo tentando evitar quaisquer hipóteses explicativas cognitivistas, mesmo tentando nos manter no domínio das hipóteses explicativas comportamentais, o recurso a crenças que não acarretam modificações de comportamento parece necessário.

Do ponto de vista comum, falamos do mesmo agente porque o identificamos com o mesmo corpo, do mesmo indivíduo humano, indicado por determinado nome próprio. Mas, do ponto de vista comportamental, esse não é o agente. De fato, estamos importando um modelo biológico para garantir a identidade daquele agente e para conferir unidade a sua ação. A solução - provisória que seja — é viável e tem sido utilizada. Mas, do ponto de vista comportamental, a solução apropriada deveria consistir em mostrar que os diversos repertórios associados ao mesmo corpo ou indivíduo biológico estão unificados em um único repertório — isto é, apresentar um modelo inteiramente comportamental. Ora, isso é um objetivo ambicioso demais quer para nossas análises comuns, quer para a própria psicologia como análise do comportamento manifesto tal como ela existe até hoje.

Principia 14(2): 279-308 (2010). 
Desse modo, uma solução alternativa consistiria em atribuir ao agente crenças que não acarretam - pelo menos diretamente - modificações de comportamento, e construir um modelo teórico de sua ação. Tais crenças é que poderiam dar consistência a nossa hipótese - mais uma vez, também descritiva - de que estamos sempre analisando episódios da ação do mesmo agente. Mas essas crenças, mais uma vez, também não se encontram mais no nível das meras hipóteses descritivas, assim como no caso daquela ideia de uma estrutura de regras que comentamos antes.

O que temos como resultado, na verdade, é uma noção limítrofe ou residual da abordagem que consiste em tomar a atribuição de crenças ou conhecimentos aos agentes da forma como relatamos acima. Isto é, do ponto de vista de nossa análise do conhecimento em termos de modificações do comportamento manifesto, a noção de crenças que não acarretam modificações de comportamento parece indispensável caso desejemos unificar os repertórios de determinado agente que estaria associado a determinado indivíduo biológico. Mas ela é indispensável apenas enquanto conceitolimite que garante a consistência dos diversos episódios de nossas análises como análises do comportamento do mesmo agente.

Em última instância, o problema de atribuir ao agente crenças que não acarretam modificações de comportamento parece estar ligado não ao entendimento de episódios isolados de seu comportamento, nem à correlação parcial de certos episódios em repertórios e dos diversos repertórios de comportamento entre si, mas, de forma mais ampla, à noção de que há um agente por trás de todas essas ações. Tal agente não é o indivíduo biológico, mas a unidade dos repertórios parciais de comportamento que ele exibe, seja isso interpretado em viés cognitivista, seja em viés comportamental. Em outras palavras, o problema reside não em entender episódios da ação do indivíduo, e oferecer modelos parciais e isolados dela, mas em apresentar um modelo geral do indivíduo como agente, como o mesmo autor das diversas ações. Tal modelo geral será necessariamente teórico por incluir algum conhecimento atribuído ao agente que não acarreta modificações de comportamento. Ele é teórico exatamente porque foge do âmbito daquelas hipóteses definidas como descritivas sobre o comportamento do agente.

Uma conclusão inevitável e que não nos surpreenderia é aquela de que nossas teorias da mente são incompletas. De fato, elas são incompletas de uma forma mais precária que aquela que incomodaria o físico realista. Por trás dos fenômenos mecânicos, mesmo os quânticos, deveria haver uma mesma natureza. Por trás das ações do mesmo indivíduo biológico deveria estar o mesmo agente. Apenas com hipóteses descritivas, nenhuma teoria em psicologia está em posição de falar de um agente único que age de diversas maneiras. Mas, seja no senso comum, seja na psicologia ou na filosofia, tem sido imperativo pensar no mesmo agente por trás de todas as suas ações. Aparentemente, todos somos realistas quanto a pessoas ou agentes humanos. Mas não há como sustentar tal ideia a não ser por meio de hipóteses explica- 
tivas que atribuem a tal agente crenças que não acarretam modificações de comportamento.

\section{Conclusão: uma teoria da investigação e da crença}

O conhecimento humano concebido da forma apresentada aqui nos leva a conceber a epistemologia como uma teoria dos processos de investigação envolvidos na ação humana, mas ela é ainda uma teoria sobre crenças ou conhecimentos dos agentes humanos. A crença (ou o conhecimento, ou a informação) entra no momento em que queremos conectar dois episódios da ação do agente. O conhecimento é, nesse caso, a mediação entre tais episódios do comportamento. Ora, tem sido comum entre epistemólogos e psicólogos descrever dessa forma o comportamento de resolver problemas. ${ }^{27}$

A solução de um problema é possível, obviamente, por meio de uma investigação. A investigação daquele indivíduo que chega a uma cidade e deseja ir a determinado endereço consiste simplesmente em perguntar a um habitante local, que lhe dá a informação, o conhecimento necessário, a regra de conduta, como dissemos. A investigação sobre a ação humana (de qualquer um de nós) também é simples, e consiste em atribuir ao agente determinada crença ou conhecimento. A epistemologia enquanto teoria do conhecimento, como vemos, não pode deixar de ser também uma teoria da investigação. E, de fato, ela deve ser prioritariamente uma teoria da investigação. Mas ela pode ser assim considerada quando não apartamos nossas crenças ou conhecimentos do mundo no qual se dá nossa ação.

Os processos de investigação - que são processos de solução de problemas são processos cuja análise permite ver de forma integrada a ação e o conhecimento, isto é, o conhecimento como resultado da ação e esta como decorrência daquele. Por isso não há conflito entre a epistemologia concebida como teoria do conhecimento ou como teoria da investigação. Nem, em última instância, haveria conflito entre as investigações sobre o conhecimento humano que focalizam os diferentes contextos, o de descoberta e o de justificação. Nos dois contextos, nossas investigações são complementares.

A atribuição de uma crença ou conhecimento a um agente, tal como analisamos acima, é a estratégia justificativa mais eficaz. O problema da justificação tem sido colocado, genericamente, da seguinte maneira: dada uma crença de um sujeito, o que pode justificá-la? Ou, em outros termos, dada uma proposição que relata tal crença do sujeito, que outras proposições, sendo aceitas, tornam também aceitável aquela proposição que relata a crença do sujeito? Ora, segundo a análise aqui apresentada, são as proposições que relatam o comportamento do agente e suas modificações que, se aceitas como hipóteses descritivas, tornam igualmente aceitável aquela proposi-

Principia 14(2): 279-308 (2010). 
ção que veicula a hipótese (também descritiva) de que tal agente possui determinada crença.

A atribuição de opiniões ou crenças a um indivíduo, como vimos neste artigo, é uma forma de entender determinado episódio de seu comportamento manifesto ou de conectar certos episódios de sua ação. Isso, contudo, ainda não oferece um retrato do indivíduo como sistema cognitivo, o que ocorre apenas quando elaboramos um modelo do indivíduo como agente, atribuindo então a ele, forçosamente, também crenças que não acarretam modificações de comportamento. Assim, o indivíduo humano pode ser retratado como um sistema cognitivo - um agente - , mas ele pode também ser retratado como elemento de um sistema cognitivo mais amplo, um sistema social. Se enfocarmos os indivíduos humanos como partes de sistemas cognitivos sociais, tais análises serão mais molares que aquelas que apresentamos neste artigo e, acreditamos, mais apropriadas para compreendermos a cognição e o conhecimento. Nesse caso, atribuímos a cognição não ao indivíduo humano, mas ao sistema social. $^{28}$

\section{Referências}

Chomsky, N. 1959. Review of B. F. Skinner's Verbal Behavior. Language 35: 26-58.

Dewey, J. 1991 [1938]. Logic: The Theory of Inquiry. The Later Works, vol. 12. Carbondale e

Edwardsville, Ill.: Southern Illinois University Press.

Dutra, L. H. de A. 2004. Behaviorismo, Operacionalismo e a Ciência do Comportamento Científico. Philósophos 9(2): 93-114.

- 2005. Oposições Filosóficas. A Epistemologia e suas Polêmicas. Florianópolis: Editora UFSC.

- 2006. Comportamento Intencional e Contextos Sociais. Uma Abordagem Nomológica. Abstracta 2(2): 102-128,

- 2008. Pragmática da Investigação Científica. São Paulo: Loyola.

- 2009. Introdução à Teoria da Ciência. 3a edição revista e ampliada. Florianópolis:

Editora UFSC.

Hutchins, E. 1996. Cognition in the Wild. Cambridge, Mass., e Londres: The MIT Press.

Lacey, H. M. 2001. Psicologia Experimental e Natureza Humana. Florianópolis: NEL/UFSC.

Popper, K. R. 1959. Logic of Scientific Discovery. Londres: Hutchinson.

Quine, W. v. O. 1969. Ontological Relativity and Other Essays. Nova York: Columbia University Press.

Rachlin, H. 1984. Behavior and Mind. The Roots of Modern Psychology. Nova York e Oxford: Oxford University Press.

- 1989. Judgment, Decision, and Choice. A Cognitive/Behavioral Synthesis. Nova York:

W. H. Freeman \& Co.

Reichenbach, H. 1938. Experience and Prediction. An Analysis of the Foundations and the Structure of Knowledge. Chicago e Londres: The University of Chicago Press.

Sellars, W. 1963. Science, Perception, and Reality. Londres: Routledge and Kegan Paul.

Principia 14(2): 279-308 (2010). 
Simon, H. A. 1996 [1969]. The Sciences of the Artificial. Cambridge, Mass., e Londres: The MIT Press.

Skinner, B. F. 1965 [1953]. Science and Human Behavior. Nova York e Londres: The Free Press.

- 1969. Contingences of Reinforcement. A Theoretical Analysis. Nova York: AppletonCentury-Crofts.

—. 1992 [1957]. Verbal Behavior. Acton, Mass.: Copley.

1999 [1950]. Are Theories of Learning Necessary? Cumulative Record. Definitive

Edition. Acton, Mass.: Copley.

Van Fraassen, Bas C. 1980. The Scienctific Image. Oxford: Clarendon Press.

- 1985. Empiricism in Philosophy of Science. In Churchland, Paul M., e Hooker, Clif-

ford A. (orgs.), Images of Science. Chicago: The University of Chicago Press: 245-308.

- 2007. A Imagem Científica. São Paulo: Editora UNESP.

Watson, J. B. 1970 [1930]. Behaviorism. Nova York e Londres: W. W. Norton \& Co.

. 1996 [1913]. Psychology as the Behaviorist Views It. In Lyons, W. (org.), Modern

Philosophy of Mind. Londres: Everyman: 24-42.

Luiz Henrique de Araújo Dutra

Departamento de Filosofia, CFH

Universidade Federal de Santa Catarina

e CNPq

Caixa Postal 5176, Florianópolis, SC, 88040-970

BRAZIL

lhdutra@cfh.ufsc.br

Resumo. Neste artigo, analisamos a relação entre a atribuição de conhecimento a um agente humano em dois tipos de situações, a saber, agir segundo as contingências ambientais e agir de acordo com uma regra. Nossa discussão parte de uma distinção que fazemos entre hipóteses descritivas e explicativas. Após estabelecer a relação entre as noções de regra e de crença, procuramos sustentar a ideia de que há precedência das modificações de comportamento manifesto sobre quaisquer atribuições de conhecimento a um agente, relacionando esse tópico com os processos de investigação. Discutimos ainda se pode haver crenças que não acarretam modificações de comportamento, defendendo que, em determinadas condições de nossa investigação sobre o comportamento das pessoas, para darmos unidade a ele, devemos atribuir a elas também crenças desse tipo. Tendo em conta tais pontos, procuramos retratar a epistemologia como uma teoria dos processos de investigação envolvidos na ação humana.

Palavras-chave: Epistemologia, cognitivismo, behaviorismo, ambientalismo, crenças, regras, ação.

\section{Notas}

${ }^{1}$ Pretendemos que o termo "comportamental" e seus correlatos se refiram a uma mera análise dos aspectos observáveis da ação das pessoas. Assim, o termo deve ser tomado de forma

Principia 14(2): 279-308 (2010). 
neutra em relação seja à perspectiva behaviorista, seja à perspectiva ambientalista que adotamos e que será especificada mais adiante. O que é, portanto, comportamental é comum a ambas as abordagens.

${ }^{2}$ Embora, em última instância, tal posição remonte a Kant, mais recentemente, o locus classicus da separação dos contextos de descoberta (ou invenção) e de justificação (ou prova) é o livro de Hans Reichenbach (1938). A mesma posição é reiterada por outros autores de filiação analítica ou próxima, no século XX, como Popper (1959). Segundo essa concepção, a epistemologia só deve se ocupar do contexto de justificação, ficando o contexto de descoberta a cargo da psicologia empírica.

${ }^{3}$ A tradição intelectualista, desde Kant e que prossegue com os autores analíticos no século $\mathrm{XX}$, inclusive os positivistas lógicos, tende a tomar a epistemologia apenas como uma teoria do conhecimento propriamente e, mais especificamente, em muitos casos, como uma teoria da justificação, tal como na epistemologia atual de língua inglesa. Entretanto, uma tradição que podemos denominar utilitarista, que remonta a Francis Bacon e que tem no século XX como principal representante John Dewey, entende que há uma continuidade entre a teoria do conhecimento e a teoria da investigação e que, além disso, devemos começar por estudar os processos de investigação, para depois podermos discutir os temas relativos à teoria do conhecimento tradicional. Sem dúvida, a principal referência sobre tal ponto de vista é o livro Logic de Dewey (1991 [1938]). Dewey denomina sua posição instrumentalista, num sentido diferente daquele associado ao termo nas recentes discussões sobre o realismo científico ( $c f$. Dutra 2005: capítulos 4 e 6), sentido atual esse que se tornou dominante na filosofia.

${ }^{4}$ Cf. Skinner 1969: cap. 6: 133-71, onde ele discute o tema das regras em relação com aquele da solução de problemas. A ideia fundamental de Skinner ali é a de que nas máximas, leis (científicas ou sociais) e regras em geral estão expressas as contingências que deram origem a tais regras. Mesmo assim, sua análise procura mostrar as diferenças entre os dois tipos de comportamento.

${ }^{5}$ Utilizamos aqui diversas expressões alternativas (como: "circunstâncias ambientais", "situação" etc.) não por falta de rigor, mas apenas para evitar a identificação imediata - e apressada - da posição que queremos defender, um tipo de ambientalismo, com aquela de Skinner, embora haja semelhanças, obviamente, uma vez que ambas as abordagens são comportamentais. Mas essa é uma característica que também compartilhamos com Simon (1996) e Hutchins (1996), embora esses autores se incluam na tradição ou perspectiva cognitivista. ${ }^{6}$ A distinção aqui proposta guarda certa semelhança com as noções evocadas por Sellars (1963), quando ele comenta (e critica) aquilo que denomina a concepção dos níveis de explicação, isto é, que as leis explicam fatos e que, por sua vez, as teorias é que explicam as leis. Comparando com essa concepção dos níveis de que fala Sellars, o que estamos afirmando seria então o seguinte: ao permitir o entendimento de fatos, as leis apenas nos dão hipóteses descritivas (razão pela qual preferimos falar em enunciados nomológicos, em vez de leis num sentido ontológico mais forte), enquanto que, por sua vez, as teorias permitiriam o entendimento de fatos e de leis por meio de hipóteses explicativas.

${ }^{7}$ Cf. van Fraassen 1980 e 2007: cap. 2. Van Fraassen critica os positivistas lógicos por quererem fazer a distinção entre observável e inobservável em termos linguísticos e fundamenta seu empirismo construtivo na referida distinção factual, citando outros autores e algumas das dificuldades para sustentar uma distinção inatacável a este respeito. De fato, em outro texto, van Fraassen (1985) fala também de limites gerais e especiais da observabilidade, mas

Principia 14(2): 279-308 (2010). 
não é preciso entrarmos nessa discussão mais detalhada do problema. O leitor interessado pode consultar também Dutra 2009: cap. 4.

${ }^{8}$ No texto já mencionado, Skinner (1969: 160s) apresenta esse mesmo exemplo para mostrar a diferença básica entre seguir uma regra e agir segundo as contingências do reforço. As regras, segundo Skinner, são formuladas a partir da observação de um comportamento bem sucedido em relação a determinado fim pretendido, vindo a constituir, assim, certo "conhecimento".

${ }^{9}$ Acreditamos que Skinner tenderia a concordar com esse ponto específico, na medida em que ele reivindicava para a psicologia uma estratégia investigativa que abrisse mão das teorias, cf. Skinner 1999 [1950]. Sobre a aversão de Skinner pelas teorias e uma elucidação sobre isso, $c f$. Dutra 2004.

${ }^{10} \mathrm{Em}$ sua análise sobre a relação entre as regras e as contingências que as originam, Skinner (1969: cap. 6) também utiliza tais termos em seu sentido corrente. Curiosamente, ele sempre utiliza "conhecimento" entre aspas para dizer que uma regra é certo conhecimento. A nosso ver, trata-se da sugestão de que o termo não está sendo tomado nem no sentido mentalista tradicional, nem no sentido cognitivista atual. Mas, no caso de nossa presente análise, esse artifício meramente terminológico não é necessário, como veremos adiante.

${ }^{11}$ Cf. Popper 1959 e Quine 1969.

12 Hutchins (1996: 129), que aborda os problemas cognitivos do ponto de vista da antropologia, diz que pretende contribuir para uma ciência cognitiva que não seja nem mentalista, e que permanece agnóstica (o termo é seu) em relação a representações internas ("na cabeça" das pessoas, diz ele), nem behaviorista, mas comprometendo-se com a análise do processamento de informação e a transformação de representações em sistemas cognitivos que são concebidos de forma ambiental, com base na noção de cognição distribuída.

${ }^{13}$ Howard Rachlin (cuja doutrina, por ele denominada behaviorismo teleológico, e que, em determinado aspecto, será criticada abaixo) apresenta também uma tentativa interessante de conciliação das perspectivas behaviorista e cognitivista (cf. Rachlin 1989). Segundo esse autor (cf. também Rachlin 1984), a diferença entre o behaviorismo e o cognitivismo consiste, respectivamente, na busca ou de causas finais, ou de causas eficientes do comportamento.

${ }^{14}$ Dito assim, obviamente, isso lembra também a abordagem de Kant dentre aquelas doutrinas tradicionais em epistemologia. De fato, embora não seja usual esse tipo de referência a Kant, e embora ele sustente, como dissemos antes, a demarcação entre uma forma de análise lógica do conhecimento (tarefa da filosofia crítica) e o estudo dos processos psicológicos correlatos (tarefa de uma forma de psicologia empírica), na medida em que elabora também uma teoria do intelecto humano, Kant pode ser visto como um precursor da psicologia cognitiva, em especial, no que diz respeito a determinados fatores constitutivos do intelecto (como as formas puras da sensibilidade e os conceitos puros do entendimento) que são, por assim dizer, ativados pela estimulação das coisas que afetam o intelecto humano.

${ }^{15}$ Como indicamos acima, a posição de Rachlin (1989), por sua vez, é peculiar no contexto da tradição behaviorista. Voltaremos a comentar sua doutrina abaixo a respeito de outro ponto específico. A distinção de Rachlin entre as perspectivas cognitivista e behaviorista (da busca pelas causas ou eficientes, ou finais do comportamento) parece um tanto simplificadora, mas, de fato, ela é bastante esclarecedora. O que temos em mente neste artigo é, contudo, um pouco diferente do que defende Rachlin (1984), como veremos abaixo.

${ }^{16}$ Outra forma de distinguir as duas abordagens (cognitivista, ou mentalista tradicional, e

Principia 14(2): 279-308 (2010). 
behaviorista) consiste em tomar a questão do controle, isto é, independentemente de que fatores (internos ou ambientais) possam estar envolvidos e contribuir para o comportamento humano, procurarmos identificar o que o controla ou, funcionalmente falando: de que variáveis o comportamento é função, internas (mentais ou cognitivas) ou ambientais? O ambientalismo, tal como o definiremos abaixo, tende a localizar tais variáveis sob cujo controle está o comportamento humano no ambiente, coincidindo em parte com o behaviorismo, portanto, mas não eliminando fatores internos, como propugnam algumas formas de behaviorismo, como o de Watson (1970; 1996), mas não exatamente o de Skinner (1965: cap. 17), propriamente falando, se levarmos em conta sua noção de comportamento encoberto. Contudo, para Skinner, o próprio comportamento encoberto está sob o controle de variáveis ambientais. Rachlin (1984), por sua vez, rejeita a noção skinneriana de comportamento encoberto por achá-la desnecessária de seu ponto de vista teleológico, isto é, de uma perspectiva ambientalista mais molar do que aquela adotada por Skinner.

17 Cf. Skinner 1969: 148. Justamente, tal como dissemos na nota anterior, a questão é sob o controle de que variáveis está o comportamento. Nesse caso, o comportamento de seguir regras está sob o controle de variáveis ambientais, mais uma vez, ainda que a regra seja, de certo modo, uma internalização.

18 Cf. Chomsky 1959. Para um exame da polêmica entre o cognitivismo de Chomsky e o behaviorismo de Skinner, cf. Lacey 2001. Sobre o comportamento verbal, $c f$. Skinner 1992 [1957], entre outros de seus escritos sobre o assunto.

${ }^{19}$ O leitor que conhece o texto de Skinner (1969: cap. 6, esp.: 160) pode ver que nossa análise difere bastante daquela ali oferecida, na qual, resumidamente temos: (1) um sistema de certas contingências de reforço; (2) o comportamento modelado e mantido por essas contingências; (3) a formulação de regras, como descrições dos passos acima; e (4) o comportamento evocado pelas regras. Nossa análise presente não é apenas alternativa àquela de Skinner, mas também mais molar que a sua, por correlacionar deferentes episódios de comportamento e procurar entendê-los em um contexto maior de ação. Na próxima seção, reapresentaremos esse esquema de forma mais completa, com uma discussão mais detalhada.

${ }^{20} \mathrm{Ou}$ seja, pelo menos as regras fundamentais que orientariam as formas básicas de comportamento, inclusive e principalmente o comportamento verbal (ou cognitivo).

${ }^{21}$ A hipótese explicativa de Skinner, segundo a qual as regras se originam de descrições das contingências que implantam e mantêm determinado comportamento, elimina, obviamente, casos limítrofes, assim como o fazem as teorias cognitivistas. Nossa hipótese ambientalista de que as regras se originam em circunstâncias do comportamento manifesto não pode pretender, é claro, dar conta de todos os casos se pretende manter-se apenas no nível descritivo. 22 Skinner (1969: 148s) procura explicar esses casos, reduzindo-os ao problema geral de explicar por que alguém segue uma regra, e argumentando que são as contingências aversivas de não segui-la ou aquelas porventura premiadoras de segui-las que explicam esse comportamento. A abordagem de Skinner, claramente, não tem em conta um contexto maior de ação. Por outro lado, a teoria de Rachlin, que já mencionamos e que voltaremos a comentar abaixo, procura explicar tais casos, propondo examinar contextos mais amplos (isto é, mais molares) de comportamento.

${ }^{23} \mathrm{E}$ também por isso podemos dizer que, no caso do visitante do primeiro exemplo, seu comportamento era o de seguir uma regra. Ele estava de posse de um conhecimento ou

Principia 14(2): 279-308 (2010). 
informação que o habitante local lhe passou.

${ }^{24}$ A posição de Rachlin (1984) é exatamente aquela segundo a qual uma adequada análise do comportamento deve ser dilatada no tempo, de modo que determinado episódio de comportamento se encaixe em um padrão maior, sendo esse compreendido como sua causa final. A ideia de referir determinado comportamento a um contexto, generalizando a estratégia teleológica de Rachlin, sem tomar isso com relação exclusivamente ao tempo, mas também a outros comportamentos de determinado contexto, é aceitável, como defendemos em Dutra 2006. Mas apenas dilatar a análise no tempo, como propõe Rachlin, não é suficiente para analisar uma série de episódios de comportamento, pois, em última instância, conduziria, por assim dizer, a uma psicologia post mortem, já que só explicaria bem o que um indivíduo faz depois de um tempo longo demais. Os próprios exemplos utilizados por Rachlin (1984) sugerem isso.

${ }^{25}$ Esse ponto, embora com apresentação diferente, é discutido também em Dutra 2008: cap. 1. A ideia central, tal como temos enfatizado também aqui, é que a atribuição de crenças ou conhecimentos às pessoas, mesmo enquanto entidades ou processos mentais ou internos, só faz sentido quando correlacionada com modificações previamente conhecidas do comportamento manifesto.

${ }^{26} \mathrm{O}$ tema tem sido amplamente discutido pelos filósofos que se dedicam aos fundamentos da mecânica quântica e é grande a literatura a respeito. A ideia geral segundo os defensores das teorias de variáveis ocultas, entre eles, o próprio Einstein, é que o caráter estatístico da mecânica quântica indicaria que ela é, de fato, incompleta, o que seria inaceitável de um ponto de vista realista.

${ }^{27}$ Cf. Skinner 1969: cap. 6, que temos citado. Cf. também autores que se tornaram referência comum sobre o tema, tal como Popper (1959) e, em especial, Dewey (1991). Cf. ainda Dutra 2008: cap. 8.

${ }^{28}$ Essa é a ideia fundamental desenvolvida por Hutchins (1996) que, contudo, não vamos discutir aqui.

Principia 14(2): 279-308 (2010). 